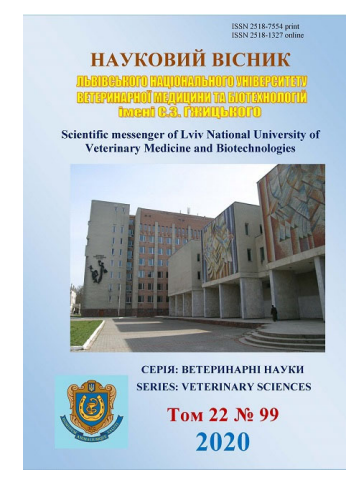

Науковий вісник Аьвівського національного університету ветеринарної медицини та біотехнологій імені С.3. Гжицького.

$$
\text { Серія: Ветеринарні науки }
$$

Scientific Messenger of Lviv National University of Veterinary Medicine and Biotechnologies. Series: Veterinary sciences doi: $10.32718 /$ nvlvet9903 https://nvlvet.com.ua/index.php/journal

UDC 615.636.09

\title{
Determination of the activity of fungicides against pathogens of dermatomycoses in domestic animals
}

\author{
I. M. Kushnir ${ }^{1}$, V. I. Kushnir ${ }^{1}$, B. V. Gutyj ${ }^{2}$, I. S. Semen ${ }^{1}$, S. D. Murska ${ }^{1}$, G. V. Kolodiy ${ }^{1}$, U. Z. Berbeka ${ }^{1}$ \\ ${ }^{1}$ State Scientific-Research Control Institute of Veterinary Medicinal Products and Feed Additives, Lviv, Ukraine \\ ${ }^{2}$ Stepan Gzhytskyi National University of Veterinary Medicine and Biotechnologies Lviv, Ukraine
}

Article info

Received 31.08.2020

Received in revised form 24.09.2020

Accepted 25.09.2020

State Scientific-Research Control Institute of Veterinary Medicinal Products and Feed Additives,

Donetska Str., 11, Lviv,

79019, Ukraine.

Tel.: +38-096-367-31-37

E-mail: igorku70@gmail.com

Stepan Gzhytskyi National University of Veterinary Medicine and Biotechnologies Lviv, Pekarska Str., 50, Lviv, 79010, Ukraine.
Kushnir, I. M., Kushnir, V. I., Gutyj, B. V., Semen, I. S., Murska, S. D., Kolodiy, G. V., \& Berbeka, $U . Z$. (2020). Determination of the activity of fungicides against pathogens of dermatomycoses in domestic animals. Scientific Messenger of Lviv National University of Veterinary Medicine and Biotechnologies. Series: Veterinary sciences, 22(99), 20-23. doi: 10.32718/nvlvet9903

The aim of the study was to identify and identify the causative agents of dermatomycosis in dogs and cats and to determine their sensitivity to solutions of ketonazole and chlorhexidine digluconate, which are part of the drug Skinhard. This is a spray for external use, manufactured by PJSC "Halychpharm". For laboratory diagnosis of dermatomycoses, samples from the affected parts of the skin and fur of domestic animals were used. To isolate a pure culture of fungi were sown on selective media: wort agar, agar Saburo, Chapek. The optimal cultivation regime for pathogenic fungi was $20-25{ }^{\circ} \mathrm{C}$. Isolated fungal cultures were identified by the appearance and shape of colonies, their consistency, color, ability to grow at $37{ }^{\circ} \mathrm{C}$, microscopic structure, in particular - the nature of mycelial branching and the presence of septa, location of conidiophores, spores and other signs. A microbiological examination of the affected areas of the skin of dogs and cats was performed to detect microscopic fungi. The following fungi were isolated from dogs affected by mycoses: Candida spp., Aspergillus niger, Epidermophyton spp., Microsporum spp., Mucor spp., Trichophyton spp., Mallasseria spp., Sporotrich spp, Candida albicans, and from cats: Microspor Candida spp., Spototrich spp., Rhizorus spp., Fusarium spp. Trichophyton spp. Isolated microscopic fungi of the genus Malassezia spp. belong to superficial mycoses (keratomycoses) and affect the superficial layers of skin and hair. Epidermatophytes: Trichophyton spp., Epidermophyton spp., Microsporum spp. affect the epidermis, skin and coat. In addition, opportunistic fungi of the genus Aspergillus spp, Mucor spp., Rhizorus spp. and Fusarium spp. Chlorhexidine digluconate was found to be highly active against dermatophytes (Trichophyton spp., Microsporum spp.), Less active against fungi of the genus Candida and less active against Aspergillus spp, Mucor spp., Rhizorus spp, Fusarium spp. Ketonazole is highly active against dermatophytes (Trichophyton spp., Epidermophyton spp., Microsporum spp.), Yeast (Malassezia spp., Candida spp.,) And opportunistic fungi (Aspergillus spp., Mucor spp., Rhizorus spp.).

Key words: chlorhexidine digluconate, ketonazole, microscopic fungi, epidermatophytes, mycoses.

\section{Визначення активності фунгіцидних засобів до збудників дерматомікозів домашніх тварин}

\author{
I. М. Кушнір ${ }^{1}$, В. І. Кушнір ${ }^{1}$, Б. В. Гутий${ }^{2}$ I. С. Семен ${ }^{1}$, С. Д. Мурська ${ }^{1}$, Г. В. Колодій ${ }^{1}$, У. З. Бербека ${ }^{1}$ \\ ${ }^{1}$ Державний науково-дослідний контрольний інститут ветеринарних препаратів та кормових добавок, \\ м. Львів, Україна \\ ${ }^{2}$ Львівський національний університет ветеринарної медицини та біотехнологій імені С. 3. Гжицького, \\ м. Львів, Україна
}

Метою дослідження було виділити та ідентифікувати збудники дерматомікозу собак та котів та визначити їх чутливість до розчинів кетоназолу та хлоргексидину диглюконату, які входять до складу препарату Скінгард. Це - спрей для зовнішнього 
застосування, виробництва ПАТ “Галичфарм”. Для лабораторної діагностики дерматомікозів використовували зразки з уражених частин шкіри та шерсті домашніх тварин. Для виділення чистої культури грибів проводили посіви на селективні середовища: сусло-агар, агар Сабуро, Чапека. Оптимальний режим культивування для патогенних грибів становив 20 -25 ${ }^{\circ} \mathrm{C}$. Виділені культури грибів ідентифікували за зовнішнім виглядом і формою колоній, ї консистенцією, кольором, здатністю до росту за температури $37{ }^{\circ} \mathrm{C}$, мікроскопічній будові, зокрема - характером розгалуження міцелію $і$ наявністю у ньому септ, розташуванню конідієносців, спор та іншими ознаками. Проведено мікробіологічне дослідження уражених ділянок шкіри собак та котів на предмет виявлення мікроскопічних грибків. Від собак, уражених мікозами виділяли наступні грибки: Candida spp., Aspergillus niger, Epidermophyton spp., Microsporum spp., Mucor spp., Trichophyton spp., Mallasseria spp., Sporotrix spp., Candida albicans, a вid котів: Microsporum spp., Candida spp., Spototrix spp., Rhizopus spp., Fusarium spp. Trichophyton spp. Виділені мікроскопічні грибки роду Маlаssеzіа spp. належать до поверхневих мікозів (кератомікозів) і уражають поверхневі шари шкіри та шерсть. Enідерматофіти: Trichорһуtоп spр., Epidermophyton spp., Microsporum spp. уражають епідерміс, икіру та шерстний покрив. Крім иього, у досліджуваних зразках виявлено опортуністичні гриби роду Aspergillus spp., Muсоr spp., Rhizopus spp. та Fusarium spp. Bстановлено, щзо хлоргексидину диглюконат високо активний до дерматофітів (Trichophyton spp., Microsporum spp.), менше активний до грибків роду Сапdida та мало активний до Aspergillus spp., Мисоr spp., Rhizopus spp., Fusarium spp. Кетоназол високо активний щзодо дерматофітів (Trichophyton spp., Epidermophyton spp, Microsporum spp.), дріжджів (Malassezia spp., Candida spp.) та до опортуністичних грибів (Aspergillus spp, Mucor spp., Rhizopus spp, Fusarium spp.).

Ключові слова: хлоргексидину диглюконат, кетоназол, мікроскопічні грибки, епідерматофіти, мікози.

\section{Вступ}

На сьогодні шкірні захворювання людей та тварин $\epsilon$ надзвичайно гострою проблемою не тільки в Україні, але й багатьох країнах світу. Серед патологій дрібних домашніх тварин домінуючу роль займають дерматози, спричинені грибковою мікобіотою. Мікроскопічні грибки, які попадають на уражену шкіру розмножуються у іiі нижніх шарах, а продукти життедіяльності викликають місцеве запалення (Nikitushkina, 2005; Martynyshyn et al., 2017).

Дуже часто дерматомікози виникають на тлі нераціонального використанням антибіотиків, особливо широкого спектру дії та різноманітних хіміотерапевтичних засобів, які послаблюють природні захисні механізми макроорганізму (LaFleur et al., 2011; Iovenko \& Koval, 2019; Kushnir et al., 2019; Borisenko et al., 2020). За високої мінливості патогенних грибків та їх здатності пристосовуватися до умов довкілля, патологічний процес значно поглиблюється, що сприяє поширенню інфекції (Koliadenko et al., 2010).

Встановлено, що дерматомікози характеризуються сезонністю прояву, природно-кліматичними факторами та чіткою видовою, віковою і породною структурою епізоотичного процесу (Bila et al., 2014). Проте, слід відзначити, що дерматомікози є поліетіологічним захворюванням, в патогенезі якого провідна роль належить таким біологічним факторам, як наявність ектопаразитів, умовно-патогенної мікрофлори та алергенів. Зокрема, умовно-патогенна мікрофлора, за умов ослаблення імунітету організму, здатна проявляти патогенні властивості та викликати різні запальні процеси (Kutsan et al., 2015).

При цьому, роль мікроскопічних грибків не зводиться лише до патологічного впливу на шкіру, але вони можуть бути причиною мікозів тварин та птиці. За дослідження, загиблої птиці на предмет виявлення мікозів, у 47 \% випадків було виявлено мікроскопічні гриби. Зокрема, з легень та повітроносних мішків загиблих курей виділяли різні види грибів: Aspergillus fumigatus, Aspergillus flavus, Mucor ramosissimus, $\mathrm{Mu-}$ cor racemosus, Mucor pusillus, Rhizopus microsporus, Candida albicans, Penicilliun notatum, Helmintosporium (Aranchii et al., 2016).
Слід відзначити, що дерматомікози домашніх тварин $є$ надзвичайно небезпечними, оскільки можуть бути джерелом інфекції для людини. Зоонози, потенційно можуть передаватися людині від домашніх тварин, а діти попадають у групу особливого ризику (Bondarenko, 2014).

Сьогодні для лікування дермотомікозів розроблено цілий ряд лікарських засобів, але не дивлячись на значну їх кількість, проблема шкірних захворювань домашніх тварин, особливо при змішаній грибковобактеріальній інфекції, залишається актуальною. 3 огляду на це, удосконалення та розроблення нових ефективних та безпечних фунгіцидних препаратів $\epsilon$ надзвичайно важливим завданням ветеринарної медицини України. Тому метою дослідження було виділити та ідентифікувати збудники дерматомікозу собак та котів та визначити їх чутливість до розчинів кетоназолу та хлоргексидину диглюконату, які входять до складу препарату Скінгард. Це - спрей для зовнішнього застосування, виробництва ПАТ “Галичфарм".

\section{Матеріал і методи досліджень}

Для лабораторної діагностики дерматомікозів використовували зразки з уражених частин шкіри та шерсті домашніх тварин. Для виділення чистої культури грибів проводили посіви на селективні середовища: сусло-агар, агар Сабуро, Чапека. Оптимальний режим культивування для патогенних грибів становив 20-25 ${ }^{\circ} \mathrm{C}$. Виділені культури грибів ідентифікували за зовнішнім виглядом і формою колоній, їх консистенцією, кольором, здатністю до росту за температури $37^{\circ} \mathrm{C}$, мікроскопічній будові, зокрема - характером розгалуження міцелію і наявністю у ньому септ, розташуванню конідієносців, спор та іншими ознаками (Sarkisov, 1971).

Фунгіцидну активність хлоргексидину диглюконату і кетоназолу визначали методом дифузії в агар, який базується на дифузії досліджуваного розчину в товщу агарової пластини. Для цього готували 2 \% розчин хлоргексидину диглюконату та $1 \%$ розчин кетоназолу, що відповідає концентрації діючих речовин в препараті Скінгард, спрей для зовнішнього застосування. Верхній шар агаризованого середовища Сабуро засівали виділеними культурами грибів, кон- 
центрацію яких визначали відповідно за стандартом каламутності на 0,5 одиниць за McFarland. У товщі агарової пластини робили лунки діаметром 8 мм, в які вносили по $0,05 \mathrm{~cm}^{3}$ досліджуваних розчинів. Чашки Петрі культивували за температури $25{ }^{\circ} \mathrm{C}$ упродовж 48 годин. Чутливість виділених ізолятів оцінювали за розмірами зон затримки росту грибів навколо лунок 3 розчинами хлоргексидину і кетоназолу.

\section{Результати та їх обговорення}

Із патологічного матеріалу, отриманого від собак та котів, виділяли широкий спектр мікроскопічних грибків. Зокрема, від собак, уражених мікозами виділяли наступні грибки: Candida spp., Aspergillus niger, Epidermophyton spp., Microsporum spp., Mucor spp., Trichophyton spp., Mallasseria spp., Sporotrix spp., Candida albicans, а від котів: Microsporum spp., Candida spp., Spototrix spp., Rhizopus spp., Fusarium spp., Trichophyton spp.

У подальшому вивчали чутливість виділених грибків до $2 \%$ розчину хлоргексидину та $1 \%$ розчину кетоназолу. Результати визначення чутливості грибкової мікрофлори, виділеної з уражених ділянок шкіри собак до хлоргексидину i кетоназол наведені в таблиці 1 .

\section{Таблиця 1}

Чутливість грибкової мікрофлори, виділеної 3 уражених ділянок шкіри собак $(\mathrm{M} \pm \mathrm{m}, \mathrm{n}=3)$

\begin{tabular}{clcc}
\hline \multirow{2}{*}{$\begin{array}{c}\text { № } \\
\text { з/п }\end{array}$} & $\begin{array}{c}\text { Виділені мікроско- } \\
\text { пічні грибки }\end{array}$ & Кетоназол & Хлоргексидин \\
\cline { 3 - 4 } & Діаметр зон затримки росту, мм \\
\hline 1 & Candida spp. & $32,6 \pm 0,6$ & $16,3 \pm 0,3$ \\
2 & Aspergillus niger & $31,6 \pm 0,8$ & $13,3 \pm 0,6$ \\
3 & Epidermophyton spp. & $29,0 \pm 0,5$ & $17,6 \pm 0,3$ \\
4 & Microsporum spp. & $29,3 \pm 0,6$ & $20,6 \pm 0,6$ \\
5 & Mucor spp. & $25 \pm 0,5$ & $13,6 \pm 0,3$ \\
6 & Trichophyton spp. & $37,3 \pm 0,6$ & $21,3 \pm 0,3$ \\
7 & Mallasseria spp. & $29,3 \pm 0,6$ & $15,3 \pm 0,3$ \\
8 & Sporotrix spp & $25,3 \pm 0,6$ & $20,6 \pm 0,3$ \\
9 & Trichophyton spp. & $41,6 \pm 0,3$ & $23,3 \pm 0,6$ \\
10 & Candida albicans & $37,3 \pm 0,6$ & $21,3 \pm 0,3$ \\
11 & Sporotrix spp & $29,6 \pm 0,3$ & $22,6 \pm 0,3$ \\
12 & Trichophyton spp. & $32,6 \pm 0,3$ & $21,3 \pm 0,6$ \\
13 & Candida spp. & $30,6 \pm 0,3$ & $18,0 \pm 0,5$ \\
14 & Mucor spp. & $28,0 \pm 0,5$ & $14,6 \pm 0,3$ \\
\hline
\end{tabular}

У результаті проведених досліджень встановили, що чутливість грибків, виділених з уражених ділянок шкіри собак до $1 \%$ розчину кетоназолу та $2 \%$ розчину хлоргексидину $\epsilon$ різна. Зокрема, $1 \%$ розчин кетоназолу проявляв значно вищу активність у порівнянні з 2 \% розчином хлоргексидину. Так, при визначенні фунгіцидної дії кетоназолу, зони затримки рос- ту різних ізолятів дерматофітів Trichophyton spp. складали від 32,6 до 41,6 мм, а при визначенні фунгіцидної дії 2 \% розчину хлоргексидину - від 21,3 до 23,3 мм. До грибів роду Candida кетоназол проявляв вираженішу фунгіцидну дію - зони затримки росту складали від 30,6 до 37,3 мм, у порівнянні з хлоргексидином - 16,3 до 21,3 мм.

Результати визначення чутливості грибкової мікрофлори, виділеної з уражених ділянок шкіри котів, до хлоргексидину і кетоназол наведені в таблиці 2.

\section{Таблиця 2}

Чутливість грибкової мікрофлори, виділеної 3 уражених ділянок шкіри котів $(\mathrm{M} \pm \mathrm{m}, \mathrm{n}=3)$

\begin{tabular}{clcc}
\hline \multirow{2}{*}{$\begin{array}{c}\text { № } \\
\text { 3/п }\end{array}$} & $\begin{array}{c}\text { Виділені мікроско- } \\
\text { пічні грибки }\end{array}$ & Кетоназол & Хлоргексидин \\
\cline { 3 - 4 } & Діаметр зон затримки росту, мм \\
\hline 1 & Microsporum spp. & $25,3 \pm 0,3$ & $22,3 \pm 0,8$ \\
2 & Candida spp. & $18,3 \pm 0,6$ & $14,6 \pm 0,3$ \\
3 & Spototrix spp & $23,6 \pm 0,3$ & $17,3 \pm 0,6$ \\
4 & Rhizopus spp. & $25,6 \pm 0,3$ & $15,6 \pm 0,3$ \\
5 & Candida spp. & $28,6 \pm 0,6$ & $16,6 \pm 0,6$ \\
6 & Microsporum spp. & $24,3 \pm 0,6$ & $21,6 \pm 0,3$ \\
7 & Trichophyton spp. & $32,6 \pm 0,6$ & $22,3 \pm 0,6$ \\
8 & Fusarium spp. & $18,3 \pm 0,3$ & $12,6 \pm 0,6$ \\
9 & Microsporum spp. & $22,3 \pm 0,6$ & $20,6 \pm 0,3$ \\
10 & Trichophyton spp. & $28,6 \pm 0,3$ & $20,6 \pm 0,3$ \\
\hline
\end{tabular}

Як видно з результатів, наведених у таблиці 2, чутливість грибків, виділених з уражених ділянок шкіри котів до $1 \%$ розчину кетоназолу є вищою, ніж до $2 \%$ розчину хлоргексидину. Зокрема, при визначенні фунгіцидної дії кетоназолу, зони затримки росту двох ізолятів дерматофітів роду Trichophyton spp. складали від 28,6 до 32,2 мм, а при визначенні фунгіцидної дії хлоргексидину - від 20,6 до 22,3 мм. Однак, фунгіцидна дія кетоназолу та хлоргексидину щодо ізолятів Microsporum spp. суттєво не відрізнялася. Зокрема, навколо лунок 3 кетоназолом зони затримки росту грибів складали від 22,3 до 25,3 мм, тоді як навколо лунок $з$ хлоргексидином - від 20,6 до 22,3 мм.

Отже, згідно проведених досліджень встановлено, що хлоргексидину диглюконат високо активний до дерматофітів (Trichophyton spp., Microsporum spp.), менше активний до грибків роду Candida та мало активний щодо Aspergillus spp., Mucor spp., Rhizopus spp., Fusarium spp. Кетоназол високо активний відносно дерматофітів (Trichophyton spp., Epidermophyton spp., Microsporum spp.), дріжджів (Malassezia spp., Candida spp.) та до опортуністичних грибів (Aspergillus spp., Mucor spp., Rhizopus spp., Fusarium spp.).

\section{Висновки}

Із уражених ділянок шкіри собак та котів виділяли різні мікроскопічні грибки, зокрема епідерматофіти 
роду Trichophyton spp., Epidermophyton spp., Microsporum spp., які уражали епідерміс, шкіру та шерстний покрив; гриби роду Malassezia spp. - уражали поверхневі шари шкіри та шерсть, а також опортуністичні гриби роду Aspergillus spp., Mucor spp., Rhizopus spp., Fusarium spp.

Виділені мікроскопічні гриби з уражених ділянок шкіри собак та котів проявлять високу чутливість до $1 \%$ розчину кетоназолу та $2 \%$ розчину хлоргексидину диглюконату, причому кетоназол проявляв вираженішу фунгіцидну дію.

\section{References}

Aranchii, S. V. Zon, H. A., \& Kinash, O. V. (2016). Epizootolohichna sytuatsiia shchodo vistseralnykh mikoziv tvaryn $\mathrm{v}$ umovakh tsentralnoho rehionu Ukrainy. Visnyk ahrarnoi nauky Prychornomoria, 2(1), 11-17. URL: https://visnyk.mnau.edu.ua/n89v2r2016aranchiy (in Ukrainian).

Bila, N. V., Hlebeniuk, V. V., Zubkov, V. V., \& Voronov, T. V. (2014). Epizootolohichni osoblyvosti dermatomikoziv u misti Dnipropetrovsk. Naukovotekhnichnyi biuleten NDTs biobezpeky ta ekolohichnoho kontroliu resursiv APK, 2(3), 63-67. URL: http://nbuv.gov.ua/UJRN/ndbnndc_2014_2_3_12 (in Ukrainian).

Bondarenko, A. V. (2014). Infektsii, shcho peredaiutsia liudyni vid domashnikh tvaryn (lektsiia). Semeinaia medytsyna, 1, 51-57. URL: http://nbuv.gov.ua/UJRN/ simmed 2014114 (in Ukrainian).

Borisenko, N. N., Bushueva, I. V., Parchenko, V. V., Gubenko, I. Ya, Mykhailiuk, Y. O., Riznyk, O. I., Aleksieiev, O. G., Gutyj, B. V., Lysianska, H. P, \& Kurinnyi, A. V. (2019). Anti-Inflammatory, Antiviral Veterinary Medicine with Immuno-Modulating Activity. Research J. Pharm. and Tech., 12(11), 5455-5459. doi: 10.5958/0974-360X.2019.00909.0.

Iovenko, A., \& Koval, G. (2019). Monitoring of contagious skin diseases of dogs and cats in Odessa. Scientific Messenger of LNU of Veterinary Medicine and Biotechnologies. Series: Veterinary Sciences, 21(93), 160-163. doi: 10.32718/nvlvet9328.
Koliadenko, V. H., Stepanenko, V. I., \& Kravchenko, A. V. (2010). Systemna terapiia mikoziv $\mathrm{z}$ urakhuvanniam osoblyvostei zhyttiediialnosti patohennykh hrybiv. Hazeta "Novyny medytsyny ta farmatsii" Dermatolohyia, 319 (Tematycheskyi nomer). URL: http://www.mifua.com/archive/issue-12119/article-12140/ (in Ukrainian).

Kushnir, I. M., Kushnir, V. I., Gufriy, D. F., Gutyj, B. V., Vishchur, V. Ya., Bushueva, I. V., Kulish, S. M., Shcherbyna, R. O., Samura, T. A., \& Stoyanovskyy, V. G. (2019). Subacute toxicity of the preparation "BiovirP'. Research Journal of Pharmaceutical, Biological and Chemical Sciences, 10(2), 674-680. URL: https://www.rjpbcs.com/pdf/2019 10(2)/[92].pdf.

Kutsan, O. T., Yaroshenko, M. O., \& Keleberda, M. I. (2015). Osoblyvosti perebihu dermatomikoziv dribnykh domashnikh tvaryn, sprychynenykh Alternaria alternata. Veterynarna medytsyna, 100, 98-102. URL: http://jvm.kharkov.ua/sbornik/100/4_26.pdf (in Ukrainian).

LaFleur, M. D., Lucumi, E., Napper, A. D., Diamond, S. L., \& Lewis, K. (2011). Novel high-throughput screen against Candida albicans identifies antifungal potentiators and agents effective against biofilms. J Antimicrob Chemother, 66(4), 820-826. doi: $10.1093 / \mathrm{jac} / \mathrm{dkq} 530$.

Martynyshyn, V., Gunchak, V., Gutyj, B., \& Hlukh, O. (2017). To the method of preparation of the liniment on the basis of thiopropyl triazole and his assessment of physical properties and performance on individual microorganisms and fungi. Scientific Messenger of LNU of Veterinary Medicine and Biotechnologies. Series: Veterinary Sciences, 19(82), 36-40. doi: $10.15421 /$ nvlvet8208.

Nikitushkina, N. A. (2005). Vidovoj sostav gribkovoj mikroflory, persistirujushhej na kozhe zhivotnyh s priznakami dermatomikoza. XII Mezhdunarodnyj moskovskij kongress po boleznjam melkih domashnih zhivotnyh. URL: http://nsau.edu.ru/images/vetfac/images/ ebooks/pages/2005/s048.htm (in Russian).

Sarkisov, A. H. (1971). Diagnostika gribnyh boleznej mikozov i mikotoksikozov zhivotnyh. M. "Kolos" (in Russian). 